\title{
Law and Power in Russia: Making Sense of Quasi-Legal Practices
}

\author{
Håvard Bækken \\ London: Routledge 2019 \\ 238 sidor. ISBN 9781138570887
}

Recenserad av Anna Jonsson Cornell [professor, Juridiska institutionen, Uppsala universitet, anna.jonsson_cornell@jur.uu.se]

Boken Law and Power in Russia: Making Sense of Quasi-Legal Practices är ett välkommet och viktigt bidrag till förståelsen av den rättsliga utvecklingen och praktiken i Ryssland och hur denna är kopplad till politiska maktcentra. Under Putins tid vid makten har nya eliter formats och makt konsoliderats i såväl formella som informella former, vilket i sin tur har präglat när och hur selektiv rättsskipning har använts som ett maktinstrument i Ryssland.

Ett övergripande syfte med boken är att beskriva och analysera ett politiskt och rättsligt system som är präglat av selektiv rättsskipning. Författaren har genom studier av sekundärkällor och intervjuer lyckats belysa bokens övergripande frågeställning, det vill säga vad som är det ryska kvasirättsliga (quasi-legal) förhållningssättets beståndsdelar, effekt och betydelse för förståelsen av förhållandet mellan rätt och makt i dagens Ryssland. En mer konkret frågeställning är kopplad till frågan om varför och hur den styrande eliten använder sig av rättssystemet och så kallad selektiv rättsskipning för att komma åt sina motståndare.

Selektiv rättsskipning definieras av författaren som en "mechanism of repression aimed at enforcing informal rules of political conduct through selective legal acts» (s. 2). Denna definition utgör kärnan av bokens analys. Författaren menar att definition också utgör det sammanfattande svaret på bokens övergripande fråga, det vill säga vad selektiv rättsskipning är och hur den fungerar. Den selektiva rättsskipningen förklaras bäst, enligt författaren, i termer av rationell legalitet kombinerat med ett så kallat beskyddarsystem (patronal system). Kombinationen av statism och byråkratisk formalism, å ena sidan, och ett patronistiskt system kombinerat med lågt förtroende för formella institutioner, å den andra sidan, skapar grogrunden för selektiv rättsskipning. Störst tonvikt läggs vid den selektiva rättsskipningens politiska syften men författaren medger att det är svårt att skilja mellan de politiska och ekonomiska aspekterna av makt och inflytande i Ryssland. 
Boken består av två delar. Den första behandlar rätt, makt och repression i auktoritära och neopatrimoniala stater generellt utifrån ett teoretiskt perspektiv. Den teoretiska kontexten tar sin utgångspunkt i den teoribildning som finns kring rättssystemens och juridikens betydelse i auktoritära stater. Boken ger oss data och underlag för att bättre förstå auktoritära regimer och deras rättssystem och bidrar så till ytterligare teoretisering och begreppsutveckling. Boken är därmed ett viktigt bidrag till den akademiska debatten kring juridikens betydelse $\mathrm{i}$ auktoritära stater och den förklarar varför en begränsad självständighet för rättsliga aktörer finns i auktoritära stater som Ryssland. Författaren beskriver hur ledare i auktoritära stater strategiskt och taktiskt förhåller sig till rätten, och hur de manipulerar rätten för att passa deras syfte. Intressant nog, och i motsats till vad många tror, så är ledare i auktoritära stater i någon bemärkelse och utsträckning beroende av självständiga domstolar.

Bokens andra del består av ett antal fallstudier där författaren redogör för sin empiri kring selektiv rättsskipning. Denna del av boken bidrar med ett underifrån och upp-perspektiv som är mycket värdefullt för att förstå utvecklingen i dagens Ryssland. Författaren lyfter fram paradoxen med att ryssarna tycks som besatta av lagen (utifrån ett formellt och legalistiskt perspektiv) samtidigt som lagen lätt kan manipuleras eller negligeras. Han beskriver på vilket sätt och varför rättsskipning används för att förfölja och oskadliggöra politiska motståndare i Ryssland. Författaren lyfter också fram hur aktivister och andra berörda anpassar sig till både informella och formella regler. Växelverkan här är mycket intressant och författaren för fram en tes eller, om man så vill, drar slutsatsen att de informella normerna formaliseras och internaliseras genom denna växelverkan.

Ett nyhetsvärde med boken är begreppet kvasi-legalitet, samt den del av analysen som visar hur ledare i auktoritära stater utformar den institutionella designen för att maximera nyttan och utfallet för den styrande eliten. Författaren menar att de egenskaper som skapar grogrunden för kvasi-legalitet och selektiv rättsskipning, det vill säga patronitism, rättslig nihilism och ett politiskt (och ekonomiskt) nollsummespel, sannolikt inte skulle påverkas av eller förändras i grunden vid ett politiskt maktskifte. Även introduktionen av en "typology of incoherence» är ett intressant bidrag till det analytiska ramverket. Typologin används för att visa hur rättssystemet används för att manipulera i tvetydiga situationer, vilket kan illustreras av behovet av flexibilitet dels för egen vinning, dels för att kunna göra anspråk på legalitet. En viktig slutsats är att selektiv rättsskipning stabiliserar regimen på kort sikt genom att upprätthålla status quo och konsolidera existerande maktrelationer. Den spänning och eventuella maktkamp som kan finnas mellan mer reformsinnade maktinnehavare och dem som primärt vill dra nytta av sin egen maktposition kan ha gynnat Putins neopatrimoniala regim i den utsträckning som den kan anses agera som en medlare mellan de två lägren. 